\title{
Przepisy archiwalne miasta Lublina z 1939 r.
}

W okresie II Rzeczypospolitej jednostki samorządu terytorialnego miały pełne prawo do rozporządzania własnymi archiwaliami, a tym samym musiały zabezpieczyć ich przechowywanie. Ówcześnie ponad 100 miast posiadało starsze akta oprócz registratur bieżących, zaś wyżej zorganizowane archiwa miejskie znajdowały się jedynie w Krakowie, Lwowie, Przemyślu, Wilnie (wszystkie powstałe jeszcze w okresie zaborczym) a także w Łodzi (od 1926 r.), Toruniu (od 1927 r.), Poznaniu i Warszawie $(\text { od } 1935 \text { r. })^{1}$.

Na krótko przed wybuchem II wojny światowej władze Lublina podjęły działania zmierzające do dołączenia do grona wyżej wymienionych miast ${ }^{2}$. Obejmowały one między innymi ustanowienie stosownych aktów normatywnych, będących przedmiotem niniejszej edycji. Wydano je jako dwa zarządzenia Prezydenta Miasta Lublina. Pierwszym był Regulamin Organizacyjny Archiwum Miejskiego (dalej: Regulamin archiwum), składający się z 58 paragrafów, pogrupowanych w 7 rozdziałów (a te w 2 części) uzupełniony czterema wzorami blankietów i pieczęci $^{3}$. Drugie to Przepisy o przechowywaniu i brakowaniu akt w kancelariach wydziałów, przedsiębiorstw i zakładów Zarządu Miejskiego w Lublinie (dalej: Przepisy o przechowywaniu i brakowaniu akt), których treść była podzielona na 41 paragrafów pogrupowanych w 6 rozdziałów z dodaniem dwóch wzorów blankietów ${ }^{4}$. Oba akty weszły w życie z dniem ogłoszenia w ,Dzienniku Zarządu miasta Lublina", co w przypadku Regulaminu archiwum nastąpiło dnia 10 lipca 1939 r.,

\footnotetext{
${ }^{1}$ H. Robótka, B. Ryszewski, A. Tomczak, Archiwistyka, Warszawa 1989, s. 380-385. I. Mamczak-Gadkowska, Archiwa państwowe w II Rzeczypospolitej, Poznań 2006, s. 242-243, 361-362. Ówcześnie propozycje dotyczące opieki nad archiwaliami samorządowymi przedstawiali m.in. J. Adamus, O archiwa miejskie i gminne [w:] Pamiętnik VI Powszechnego Zjazdu Historyków Polskich w Wilnie 17-20 września 1935 r., t. 1., Lwów 1935, s. 425-431 oraz E. Barwiński, O archiwa miejskie i gminne (koreferat), tamże, s. 432-438.

${ }^{2} \mathrm{O}$ rozpoczęciu w latach trzydziestych organizowania archiwum miejskiego i podjęciu pierwszych prac porządkowych wzmiankują źródła archiwalne: Archiwum Państwowe w Lublinie, Akta miasta Lublina 1918-1939, sygn. 401 i 411. Por: J. Marczuk, Rada Miejska i Magistrat Lublina 19181939, Lublin 1984, s. 266; F. Petruczynik, Rada Artystyczna Miasta Lublina w latach 1935-1937, „Pamiętnik Lubelski”, t. 3, 1938, s. 506.

${ }^{3}$ Dziennik Zarządu miasta Lublina 1939, nr 2, s. 55-66.

${ }^{4}$ Dziennik Zarządu miasta Lublina 1939, nr 3, s. 56-61.
} 
natomiast Przepisy o przechowywaniu i brakowaniu akt opublikowano dnia 7 września $1939 \mathrm{r}$.

W przedstawionych tutaj aktach normatywnych ustanowiono miejską służbę archiwalną, realizującą zadania administracyjne i naukowe. Jej podstawowym ogniwem miało być Archiwum Miejskie, którego kierownik podporząadkowany był Naczelnikowi Wydziału Ogólnego Zarządu Miejskiego. Składać się ono miało z Sekcji Akt Dawnych oraz z Centralnej Składnicy Akt. Ta ostatnia zajmować się miała przechowywaniem, porządkowaniem i udostępnianiem akt zamkniętych przekazanych przez składnice poszczególnych instytucji miejskich, a także ich brakowaniem oraz przekazywaniem do Sekcji Akt Dawnych. Organem doradczym Prezydenta Miasta w sprawach archiwalnych miała być Rada Archiwalna, której skład, zakres i tryb funkcjonowania określić miał osobny regulamin.

Przepisy, w zakresie archiwizowania i brakowania narastającej dokumentacji obowiązywały wszystkie jednostki organizacyjne samorządu miasta Lublina, a mianowicie Zarząd Miejski składający się z wydziałów, przedsiębiorstwa miejskie i wreszcie o zakłady miejskie. O zakresie przedmiotowym przepisów decydowała szeroka definicja akt obejmująca dokumentację pisaną, rysunki, fotografie czy pieczęcie (Regulamin..., par. 25).

Omawiane normatywy kompleksowo regulowały całą procedurę archiwizacji akt wytwarzanych przez samorząd miejski. Pierwszy jej etap miał przebiegać w kancelariach aktotwórców, drugi w Centralnej Składnicy Akt, a końcowy dla dokumentacji podlegającej wieczystemu przechowywaniu w Sekcji Akt Dawnych Archiwum Miejskiego. Przewidziano podział akt na kategorie i grupy zależnie od czasu ich przechowywania (Regulamin..., par 28) oraz określono szczegóły procedur ich brakowania w kancelariach oraz przekazywania (Przepisy..., par 4-22 i Regulamin..., par 33-38). Uregulowano tu również wykonywanie zadań Centralnej Składnicy Akt - przejmowanie, przechowywanie, ewidencjonowanie i udostępnianie akt oraz ich brakowanie i przekazywanie do Archiwum Miejskiego (Regulamin..., par 39-54). Do zadań tego ostatniego miało należeć gromadzenie, porząakowanie, przechowywanie i udostępnianie na określonych w regulaminie zasadach (Regulamin..., par 8-23) materiałów archiwalnych powstałych w toku funkcjonowania gminy miasta Lublina, a także odnoszących się do dziejów i kultury Lublina oraz regionu lubelskiego. Z tym wiązać się miało prowadzenie działalności naukowej i popularyzatorskiej w zakresie dziejów Lublina i regionu (Regulamin..., par. 1).

Pod względem legislacyjnym przedstawione wyżej normy zostały zawarte w tekstach dwóch aktów normatywnych. Wiodące znaczenie miał Regulamin Organizacyjny Archiwum Miejskiego w Lublinie (choćby ze względu na zawarte regulacje ustrojowe archiwum miejskiego oraz Centralnej Składnicy Akt). Do ustalonych w nim procedur archiwizowania dokumentacji odsyłały bezpośrednio (np. w par. 3 i 28) lub pośrednio (par. 3) Przepisy o przechowywaniu i brakowaniu akt, przeznaczone do stosowania przez jednostki organizacyjne wytwarzające dokumentację. 
Trzecim istotnym normatywem miał być regulamin Rady Archiwalnej, którego wydanie zapowiedziano w par. 7 Regulaminu archiwum.

Podstawę wydania niniejszych źródeł stanowią teksty oficjalnie, ogłoszone w urzędowym wydawnictwie „Dziennik Zarządu miasta Lublina”. W przypadku tekstów Przepisów o przechowywaniu i brakowaniu akt należy zwrócić uwagę na ukazanie się odnośnego numeru „Dziennika” już po wybuchu II Wojny Światowej (z datą 7 września 1939 r.) $)^{5}$. W edycji uwzględnione zostały wytyczne zawarte $\mathrm{w}$ projekcie instrukcji wydawniczej dla źródeł historycznych XIX i XX wieku autorstwa Ireneusza Ihnatowicza ${ }^{6}$. Zgodnie $\mathrm{z}$ nimi dokonano modernizacji pisowni w zakresie form odmiany rzeczowników i interpunkcji. Bez ingerencji pozostawiono drobne niekonsekwencje terminologiczne i redakcyjne. Podstawa wydania tekstu Przepisów o przechowywaniu i brakowaniu akt zawiera niewielkie opuszczenie tekstu w par. 21, którego nie uzupełniono, gdyż w zespole archiwalnym Akta miasta Lublina, przechowywanym w zasobie Archiwum Państwowego w Lublinie nie udało się natrafić na teksty obu normatywów przed skierowaniem ich do druku. Nie odnaleziono tam również tekstu, względnie projektu regulaminu Rady Archiwalnej. Obecny stan badań nie pozwala również na ustalenie autorstwa przedmiotowych aktów normatywnych.

Zaprezentowane tu przepisy stanowią źródło do badań nad historią archiwum miejskiego w Lublinie, a w szerszym kontekście historii archiwistyki miejskiej w II Rzeczypospolitej, choć otwartym problemem badawczym pozostaje kwestia ich praktycznego stosowania $\mathrm{w}$ funkcjonowaniu archiwum miejskiego w latach 1939-1951. Niniejsze normatywy jako takie stanowią też przejaw pewnej koncepcji kompleksowego zarządzania narastającą dokumentacją zarówno u aktotwórców, jak i w archiwum przejściowym aż po archiwum historyczne.

\footnotetext{
${ }^{5}$ Jedyny znany Autorowi egzemplarz „Dziennika Zarządu miasta Lublina” z 1939 nr 3 znajduje się w zbiorach Biblioteki Archiwum Państwowego w Lublinie.

${ }^{6}$ I. Ihnatowicz, Projekt instrukcji wydawniczej dla źródet historycznych XIX i poczq̨tku XX wieku, „Studia Źródłoznawcze” t. 7, 1962, s. 99-123.
} 


\title{
Nr 1
}

\section{VII 1939 r.}

\section{druk: Dziennik Zarządu m. Lublina z dnia 10 lipca 1939 r., nr 2, s. 56-66}

Regulamin Organizacyjny Archiwum Miejskiego w Lublinie wydany na podstawie art. 46 ustawy z dnia 23 marca 1933 roku o częściowej zmianie ustroju samorządu terytorialnego (Dz. U. R. P. Nr 35, poz. 294) po zasięgnięciu opinii Kolegium Zarządu Miejskiego w Lublinie.

\section{Część I}

Postanowienia ogólne

\author{
Rozdział 1. \\ Zadania \\ $\S 1$.
}

Archiwum Miejskie jest instytucją Gminy m. Lublina, powołaną do administrowania miejskim majątkiem archiwalnym, a w szczególności do:

1) gromadzenia, porządkowania i przechowywania akt i dokumentów, które powstają wskutek czynności urzędowych gminy, jak również wszelkiego rodzaju zabytków archiwalnych, odnoszących się do dziejów i kultury Lublina i regionu lubelskiego; 2) udostępniania akt zainteresowanym i sporządzania dokumentów uwierzytelnionych;

3) prowadzenia prac naukowych oraz popularyzacyjnych z zakresu badań nad dziejami Lublina i regionu lubelskiego;

4) nadzorowania pod względem fachowym registratur i składnic akt poszczególnych instytucji miejskich, oraz szkolenia w miarę potrzeby pracowników miejskich w zakresie registraturalno-archiwalnym:

5) opiniowania wniosków, projektów zarządzeń i poczynań organizacyjnych z zakresu biurowości, oraz brania udziału w pracach nad organizacją kancelarii, instytucji pod kątem widzenia potrzeb archiwalnych,

Rozdział II.

Organizacja i podział zadań

$\S 2$.

Archiwum Miejskie dzieli się na:

1) Sekcję Akt Dawnych (Archiwum Historyczne),

2) Centralną Składnicę Akt.

\section{$\S 3$.}

A. Do zadań Sekcji Akt Dawnych należy konserwacja, porządkowanie i udostępnianie instytucjom i osobom zainteresowanym akt o charakterze ściśle archiwalnym, oraz prowadzenie prac naukowych. 
B. W skład Sekcji wchodzą:

1) Dział Akt Staropolskich, obejmujący akta z okresu przedrozbiorowego,

2) Dział Akt Porozbiorowych, obejmujący akta z okresu porozbiorowego (do 1915 r.),

3) Dział Akt Samorządu Odrodzonego obejmujący akta od r. 1915 w miarę, ich przekazywania z Centralnej Składnicy Akt,

4) Dział kolekcji, obejmujący zbiory rękopisów, map, planów, grafiki, fotografiki, pieczęci, materiałów do kroniki bieżącej miasta itp.,

5) Biblioteka, obejmująca druki, dotyczące Lublina, oraz wydawnictwa: a) z zakresu dziejów miast i mieszczaństwa, b) z zakresu zagadnień archiwalnych, c) inne niezbędne do prac Archiwum.

\section{$\S 4$.}

Do zadań Centralnej Składnicy Akt należy konserwacja, porządkowanie i udostępnianie instytucjom i osobom zainteresowanym współczesnych akt zamkniętych, przekazanych przez składnice poszczególnych instytucji miejskich.

\section{Rozdział III.}

Kierownictwo i personel

$\S 5$.

Na czele Archiwum Miejskiego stoi kierownik, podległy Naczelnikowi Wydziału Ogólnego.

Kierownik jest zwierzchnikiem wszystkich pracowników Archiwum.

Kierownika Archiwum zastępuje wyznaczony przez Naczelnika Wydziału Ogólnego pracownik, który ponosi odpowiedzialność za powierzony mu dział pracy przez kierownika Archiwum, zaś w okresie całkowitego zastępstwa za całokształt działalności Archiwum przed Naczelnikiem Wydziału Ogólnego.

Za całokształt prac w Archiwum Miejskim ponosi odpowiedzialność przed Prezydentem Miasta - Naczelnik Wydziału Ogólnego.

\section{$\S 6$.}

Ilość pracowników Archiwum określa statut etatów stanowisk służbowych, zaś zakres ich działania w ramach niniejszego regulaminu określi Naczelnik Wydziału Ogólnego po porozumieniu się z kierownikiem Archiwum.

\section{Rozdział IV.}

\section{Rada Archiwalna}

$\S 7$.

Organem doradczym Prezydenta Miasta w sprawie Archiwum Miejskiego jest Rada Archiwalna, która opiniuje prace Archiwum w zakresie naukowym i fachowo archiwalnym.

Przewodniczącym Rady Archiwalnej jest Prezydent Miasta, względnie wyznaczony przez niego zastępca. 
Skład Rady, zakres jej działania i sposób urzędowania ustali osobny regulamin wydany przez Prezydenta Miasta.

Część II.

Postanowienia szczegółowe

Korzystanie z Archiwum Miejskiego

Rozdział V.

$\S 8$.

Osobiście w Archiwum mogą korzystać z materiałów archiwalnych dla celów naukowych, urzędowych lub prywatnych:

a) osoby znane Zarządowi Miejskiemu w Lublinie ze swej działalności naukowej,

b) osoby mające polecenie instytucji naukowych lub osób znanych Zarządowi Miejskiemu w Lublinie ze swej działalności naukowej,

c) urzędnicy samorządu terytorialnego i państwowi, mający pisemne polecenie swej władzy przełożonej w określonym celu urzędowym.

$\S 9$.

Pozwoleń na korzystanie z Archiwum w celach naukowych udziela Naczelnik Wydziału Ogólnego na wniosek kierownika Archiwum.

Udzielenie pozwolenia nastąpić może zasadniczo tylko na podanie, w którym winien być wymieniony dokładnie cel, przedmiot i granice chronologiczne badań.

Petentowi służy prawo odwołania od decyzji Naczelnika do Prezydenta Miasta, którego decyzja jest ostateczna. Do poszukiwań w sprawach majątku i prawnych interesów m. Lublina, oraz jego urzędów potrzeba zezwolenia Prezydenta Miasta.

Z akt ostatnich lat 30 można korzystać dopiero po uzyskaniu osobnego zezwolenia.

Wyjątkowo Naczelnik Wydziału Ogólnego może udostępnić uczonym żądane akta bez uprzedniego załatwienia wymienionych w niniejszym paragrafie formalności.

Podania, składane o korzystanie z Archiwum w celach naukowych opłatom nie podlegają.

$\S 10$.

Dla korzystania $\mathrm{z}$ akt w celach prywatnych osoba zainteresowana, w podaniu swym o udostępnienie akt winna zaznaczyć do jakiego celu akta te są potrzebne.

Przy wydawaniu decyzji w sprawie udostępnienia akt stosuje się odpowiednio ust. 1, 2, 3, 4 poprzedniego paragrafu.

$\S 11$.

Wierzytelne odpisy i wyciągi wydaje Archiwum władzom samorządowym w Lublinie i państwowym bezpłatnie, innym zaś interesantom za opłatą archiwalną. Wysokość opłat normuje Statut Opłat Kancelaryjnych. 
Wydawanie odpisów z wewnętrznej, a zwłaszcza poufnej korespondencji urzędów lubelskiego samorządu miejskiego z ostatnich 30 lat jest dozwolone tylko za zgodą Prezydenta Miasta.

\section{$\S 12$.}

Osoby korzystające z archiwum nie mogą bez zezwolenia Naczelnika Wydziału Ogólnego podejmować prac, mających na celu układanie i publikowanie spisów, zestawień, repertoriów itd. dla użytku prywatnego lub publicznego.

$\S 13$.

Obywatelem obcym pozwoleń na osobista pracę w Archiwum udziela Naczelnik Wydziału Ogólnego na skutek polecenia tych osób przez przedstawicieli dyplomatycznych odnośnych państw. Obywatel obcy, przybyły na krótko lub bawiący przejazdem, może być w drodze wyjątku, dopuszczony do pracy naukowej w Archiwum bez dopełnienia tych formalności.

$\S 14$.

Osoby pracujące naukowo mogą korzystać, za zezwoleniem Naczelnika Wydziału Ogólnego z sprowadzonych przez siebie, zaufania godnych kopistów. Za sprowadzonego przez siebie kopistę, oraz za treść i formę dokonanych wypisów przez kopistę odpowiada osoba pracująca naukowo.

\section{$\S 15$.}

Osoby wymienione w niniejszym regulaminie korzystają z materiałów archiwalnych tylko w pracowni naukowej, pozostającej pod stałym dozorem urzędnika i winny stosować się ściśle do przepisów niniejszych.

$\S 16$.

Urzędnicy archiwalni winni osobom zainteresowanym udzielać informacji o materiale archiwalnym.

\section{$\S 17$.}

Osoby, pracujące naukowo mogą korzystać z całego materiału archiwalnego, dotyczącego zgłoszonego tematu. Wiadomości prywatnej natury, które korzystający czerpie z akt mu wydanych nie wolno rozgłaszać, ani zużytkowywać pisemnie pod rygorem zamknięcia dostępu do Archiwum.

Osoba ogłaszająca pracę, opartą na materiałach Archiwum, zobowiązana jest złożyć w Archiwum Miejskim 2 egzemplarze tej pracy.

\section{$\S 18$}

W wyjątkowych wypadkach Archiwum, za zgodą Naczelnika Wydziału Ogólnego wypożyczy za pokwitowaniem pisemnym na wniosek urzędu państwowego 
lub samorządowego, akta istotnie dla tego urzędu niezbędne do załatwienia spraw bieżących.

Jednakże Archiwum odmówi przesłania akt zainteresowanemu urzędowi jeżeli niezadawalający stan akt, ich specjalna wartość, albo potrzeba częstego użycia w Archiwum za tym przemawiają.

$\S 19$.

Archiwum obowiązane jest na wniosek urzędów państwowych i miejskich złożony na piśmie dokonywać, zgodnie z $§ 11$ niniejszego regulaminu, poszukiwań i sporządzać odpisy.

Jeżeli jednak wykonanie tych prac czyniłoby uszczerbek w należytej służbie wewnętrznej Archiwum, wówczas czynności, o których mowa w ustępie pierwszym wykona dany urząd własnymi siłami i na własny koszt.

$\S 20$.

Archiwum Miejskie może porozumiewać się z polskimi i zagranicznymi instytucjami naukowymi, z wyższymi uczelniami, towarzystwami naukowymi, z archiwami i bibliotekami państwowymi, publicznymi i prywatnymi, zwłaszcza posiadającymi zbiory rękopiśmienne.

\section{$\S 21$.}

Archiwista ${ }^{a}$, z wyjątkiem akt uznanych za cenne, oraz takich co do których istnieją zastrzeżenia odnośnie ich wytrzymałości, mogą być przesyłane do użytku instytucji, wymienionych $\mathrm{w} \S$ poprzedzającym, względnie osób przez nie do badań nad danym tematem upoważnionych. Akta mogą być wypożyczane tylko instytucjom, które mają odpowiednie pomieszczenie do przechowania archiwaliów oraz odpowiednio urządzoną pracownię naukową.

\section{$\S 22$.}

Wypożyczenie archiwaliów może mieć miejsce, poza warunkami wymienionymi w $\S \S$ poprzedzających, tylko w wypadku całkowitej pewności co do ich odpowiedniego zabezpieczenia, oraz tylko pod warunkiem zwrotu w terminie przez Archiwum określonym.

$\S 23$.

Osoby, korzystające z materiałów archiwalnych winny obchodzić się ostrożnie $\mathrm{z}$ archiwaliami i zachowywać w nich porządek. Akta przechowywane luźno winny być układane w tym samym porządku, w jakim je osoba korzystająca $\mathrm{z}$ nich otrzymała. Nie wolno zmieniać kolei aktów w fascykułach i kartonach, nawet w tych wypadkach, gdy kolej ta uznana została przez osobę pracującą nad nimi za wadliwą.

\footnotetext{
"Winno być „Archiwalia”.
} 
W szczególności osobom korzystającym z pracowni Archiwum nie wolno:

a) palić tytoniu w pracowni,

b) czynić notatek, znaków lub dopisków na archiwaliach,

c) samowolnie dokonywać odcisków pieczęci,

d) dokonywać facsimiliów przez kalkę,

e) używać odczynników,

f) kłaść papieru na aktach w czasie pisania na nim,

g) umieszczać kałamarze po lewej stronie przepisywanych archiwaliów.

Wszelkich reprodukcji archiwaliów dokonywać można jedynie za każdorazowym wyraźnym zezwoleniem kierownika Archiwum.

Niestosowanie się do tych przepisów pociąga za sobą pozbawienie prawa korzystania z pracowni Archiwum.

\section{Rozdział VI.}

Centralna Składnica Akt

\section{$\S 24$.}

Miano centralnej składnicy akt - nazywanej dalej ,składnicą” nosi komórka organizacyjna Zarządu Miejskiego w Lublinie, której zadaniem jest przechowywanie akt zakończonych, niepotrzebnych do pracy bieżącej.

Składnica jest wspólna dla wszystkich wydziałów, urzędów i przedsiębiorstw Zarządu Miejskiego.

\section{$\S 25$.}

Akta - w rozumieniu niniejszej instrukcji - oznaczają wszelkiego rodzaju utrwalone pismem lub w inny sposób przejawy działalności Zarządu Miejskiego, a mianowicie: korespondencję w postaci teczek lub przechowywanej luźno, księgi buchalteryjne, dowody do księgowania, dowody kasowe, bilanse, księgi protokółów, zestawienia statystyczne, sprawozdania, regulaminy, instrukcje, okólniki, plany, wykresy, rysunki, fotografie, pieczęcie, stemple itp.

\section{$\S 26$.}

Określenie, ,akta zakończone” w rozumieniu niniejszej instrukcji - ma dwojakie znaczenie:

1) oznacza akta zakończone pod względem merytorycznym, z uwagi na całkowite zakończenie się korespondencji, związanej z zagadnieniem;

2) oznacza część akt zakończonych pod względem formalnym z uwagi na wypełnienie tomu księgi itp.

\section{$\S 27$.}

Akta zakończone przechowuje się w kancelarii odnośnej jednostki administracyjnej zasadniczo dwa lata. 
Po upływie tego czasu akta przekazuje się do składnicy.

$\S 28$.

Ze względu na czas przechowywania akta dzielą się na dwie kategorie:

1) akta kat. a, które będą przechowywane stale $i$

2) akta kat. b, które będą przechowywane czasowo.

Do kat. a należą akta posiadające trwałe znaczenie dla:

a) interesu i historii Państwa,

b) interesu i historii miasta Lublina i regionu lubelskiego,

c) praw obywateli.

Dokumenty, stanowiące własność prywatną, traktuje się jak akta kat. a.

Do akt b, należą akta, których nie zaliczono do kat. a.

Akta kat. b, dzielą się na cztery grupy: I. II, III, IV.

Do I grupy zalicza się akta, przechowywane przez 35 lat po ich zakończeniu, do II grupy - przechowywane przez 20 lat, do III grupy - przechowywane przez 10 lat i do IV grupy - przechowywane przez 2-5 lat.

\section{$\S 29$.}

Składnica przechowuje akta przez: czas do 10 lat.

Po upływie tego czasu akta kat. a, będą przekazane do Sekcji Akt Dawnych, akta zaś kat. b, będą zniszczone w odpowiednich terminach, w zależności od grupy, do której je zaliczono.

\section{$\S 30$.}

Akta własne składnicy prowadzić należy zgodnie z instrukcją kancelaryjną, obowiązującą w Zarządzie Miejskim w Lublinie.

\section{$\S 31$.}

Bezpośrednim zwierzchnikiem centralnej składnicy akt jest urzędnik mianowany przez Naczelnika Wydziału Ogólnego po porozumieniu z kierownikiem Archiwum.

Do obowiązków tego urzędnika należy:

a) przyjmowanie akt od poszczególnych jednostek administracyjnych,

b) utrzymywanie w porządku akt przechowywanych w składnicy,

c) wypożyczanie akt,

d) przekazywanie akt do sekcji Akt Dawnych,

e) brakowanie akt,

f) wykonywanie wszelkich innych czynności, związanych z prowadzeniem składnicy.

Lokal składnicy winien być urządzony i utrzymany w sposób gwarantujący całkowite bezpieczeństwo przechowywanym aktom, winien posiadać dostateczną ilość półek, ustawionych tak, by dostęp do każdego tomu był łatwy. W szczególności w magazynie należy utrzymać temperaturę umiarkowaną, zapobiegać wilgoci, 
codziennie przewietrzać (z wyjątkiem dni niepogodnych) w miarę posuchy odkurzać i stale chronić od myszy i robactwa.

\section{$\S 32$.}

Wydziały, przedsiębiorstwa itp. przekazują do składnicy akta zakończone, niepotrzebne do pracy bieżącej, po przechowaniu tych akt przez 2 do 5 lat.

Akta przekazuje się jednorazowo w ciągu pierwszych trzech miesięcy roku kalendarzowego.

Po porozumieniu się z kierownikiem Archiwum wydział lub przedsiębiorstwo może przekazać akta do składnicy również w innym terminie.

\section{$\S 33$.}

Przed przekazaniem do składnicy:

a) akta należy uporząadkować zgodnie z przepisami, według których były utworzone, b) wydzielić akta kat. b gr IV (przechowywane 2 do 5 lat).

\section{$\S 34$.}

O zamiarze przekazania akt do składnicy przekazująca jednostka administracyjna zawiadamia kierownika Archiwum.

Otrzymawszy zawiadomienie, kierownik Archiwum udaje się do kancelarii danej jednostki administracyjnej, gdzie w obecności registratora bada stan akt i w razie potrzeby udziela wskazówek co do ich ostatecznego uporządkowania.

Braki ujawnione w trakcie badania należy usunąć najdalej w ciągu miesiąca.

\section{$\S 35$.}

Wydział (przedsiębiorstwo, zakład) przekazujący sporządza na maszynie w trzech egzemplarzach wykaz zdawczo-odbiorczy.

Do wykazu wpisuje się przekazywane akta w kolejności chronologicznej, oraz $\mathrm{w}$ takim porządku w jakim figurują one w wykazie akt wydziału.

Akta figurujące pod jednym tytułem, wpisuje się do wykazu pod jedną pozycją.

Akta kat. B, gr. IV wpisuje się do wykazu po wszystkich innych aktach.

Po wpisaniu akt należy podsumować ilość pozycji wykazu, oraz ilość tomów, a następnie wypisać klauzulę: Razem, jednostek akt $\mathrm{w}$ tomach przekazał....... przyjął ......

\section{$\S 36$.}

Jednostka administracyjna odsyła akta do składnicy własnymi siłami, pod nadzorem registratora,

\section{$\S 37$.}

Akta przekazywane przyjmuje kierownik Archiwum, lub zastępujący go urzędnik, w obecności registratora, według wykazu zdawczo-odbiorczego. 
Wszystkie egzemplarze wykazu zdawczo odbiorczego podpisują: registrator i kierownik Archiwum.

Dwa egzemplarze wykazu wraz z aktami pozostają w składnicy, trzeci zaś otrzymuje przekazująca akta jednostka administracyjna.

\section{$\S 38$.}

W przypadkach ujawnienia błędu lub niedokładności w wykazie zdawczo-odbiorczym, stwierdzenia, że akta przekazywane nie odpowiadają wykazowi, ustalenia, że wykaz nie został sporządzony prawidłowo, lub stwierdzenia, że akta nie zostały uporządkowane zgodnie z przepisami - kierownik Archiwum może odmówić przyjęcia przekazywanych akt.

O powodach nie przyjęcia kierownik Archiwum zawiadamia zwierzchnika odnośnej jednostki administracyjnej.

\section{$\S 39$.}

Składnica prowadzi spis wykazów zdawczo-odbiorczych, przy czym na jednej stronicy wpisuje nie więcej jak 10 wykazów.

Pozycje spisu mają kolejną numerację, nie ulegającą przerwie. Kolejnemu numerowi pozycji odpowiada kolejny numer wykazu zdawczo-odbiorczego.

Przy wciąganiu wykazu do wpisu stawia się numer kolejny na wszystkich egzemplarzach wykazu.

Wykazy przechowuje składnica:

1) pierwsze egzemplarze w kolejności numerów spisu,

2) drugie egzemplarze według wydziałów - chronologicznie.

Akta składnica układa według wydziałów.

Akta jednego wydziału nie powinny stykać się bezpośrednio z aktami innego wydziału.

Dla każdego wydziału należy zarezerwować - o ile to możliwe miejsce na akta co najmniej z lat 10 .

W obrębie wydziałów akta układa się według oddziałów lub referatów, a w obrębie referatów - jednorodnymi grupami w porządku chronologicznym.

Wyjątek stanowią:

1) Księgi buchalteryjne, które ustawia się według formatów, a w obrębie pewnego formatu - według wydziałów i rodzajów ksiąg w porządku chronologicznym,

2) Akta formatu zupełnie odmiennego od zwykłych, które układa się lub ustawia na osobnych półkach.

Akta kat. B. gr. IV (przechowywane 2 do 5 lat) umieszcza się na osobnej półce oddzielnie od reszty akt. 


\section{$\S 41$.}

Księgi i akta oprawne ustawia się na półkach tak, jak książki. Inne akta układa się grzbietem ku górze.

Należy unikać zbyć ciasnego ustawienia akt.

\section{$\S 42$.}

Dowody kasowe i akta tajne przechowuje się w szafach zamkniętych.

\section{$\S 43$.}

Przed ustawieniem na półce, należy na każdym przyjętym akcie wycisnąć stempel składnicy.

W księgach stempel wyciska się na pierwszej czystej karcie, w aktach na pierwszej stronie okładki.

Wewnątrz stempla wpisuje się:

a) sygnaturę aktu (atramentem),

b) numer szafy i półki (ołówkiem zwykłym).

Sygnaturą aktu jest numer odpowiedniego wykazu zdawczo-odbiorczego dzielony przez numer odpowiedniej pozycji tego wykazu.

Ponadto sygnaturę wpisuję się (ołówkiem kolorowym) na wierzchniej stronie okładki, na lewo: a) na księgach i aktach oprawnych u góry, b) na aktach broszurowych $-\mathrm{u}$ dołu.

Numer szafy i półki wpisuje się (ołówkiem zwykłym) jednocześnie do wykazu zdawczo-odbiorczego obok tytułu.

\section{$\S 44$.}

Poszukiwania w aktach oraz sporządzanie z nich odpisów należą do zainteresowanej jednostki administracyjnej. W tym celu wydziały mogą wypożyczać akta ze składnicy lub przeglądać je na miejscu.

Wypożyczać można tylko całe teczki.

\section{$\S 45$.}

Nic wolno wypożyczać poza lokal składnicy:

a) wykazów zdawczo-odbiorczych i ich opisu ${ }^{\mathrm{b}}$,

b) kartotek,

c) protokółów,

d) akt tajnych,

e) dowodów kasowych.

Wyjątek stanowi wydawanie akt władzom sądowym.

\footnotetext{
' Winno być „spisu”.
} 
$\S 46$.

Zainteresowana jednostka administracyjna może wypożyczać akta innej jednostki administracyjnej tylko za zgodą jej zwierzchnika, wyrażoną na karcie wypożyczenia.

\section{$\S 47$.}

Składnica wypożycza akta na czas nieprzekraczający 1 miesiąca.

Odpowiedzialność za całość i należyte przechowywanie wypożyczonych akt ponoszą urzędnicy, podpisujący zapotrzebowanie akt.

Niedopuszczalne jest wyjmowanie pism lub dokumentów z akt wypożyczonych.

Wyjątek stanowią dokumenty zwracane petentowi (§ 28 ust. 3).

Akt wypożyczonych nie wolno zabierać z lokali Zarządu Miejskiego.

\section{$\S 48$.}

Wypożyczanie akt ze składnicy odbywa się na podstawie karty wypożyczenia.

Pierwszą część karty wypełnia wypożyczająca jednostka administracyjna,

Wypożyczająca jednostka administracyjna odbiera i odsyła akta do składnicy przez swoich pracowników lub woźnych.

Odbierający akta zgłasza się do składnicy z kartą wypożyczenia.

Przy zwrocie akt urzędnik składnicy sprawdza, czy akta wróciły w takim stanie, w jakim je wypożyczono, po czym w drugiej części karty wypożyczenia potwierdza zwrot akt, z zaznaczeniem daty. Odcinek (drugą część karty) odrywa i wręcza oddającemu akta.

W razie potrzeby urzędnik składnicy, czyni adnotacje w rubryce ,uwagi” karty wypożyczenia o nieznacznych brakach, zauważonych przy zwrocie akt. Adnotację podpisują: oddający akta i urzędnik składnicy.

Akta zwrócone należy niezwłocznie złożyć na właściwym miejscu.

\section{$\S 49$.}

W razie: a) zaginięcia wypożyczonych akt, b) poważnego ich uszkodzenia, c) braku w nich kart, dokumentów, czy załączników - urzędnik składnicy obowiązany jest niezwłocznie sporządzić w obecności oddającego akta protokół w trzech egzemplarzach. Protokół podpisują: oddający akta i przyjmujący.

Celem nadania sprawie właściwego biegu, jeden egzemplarz protokółu przedstawia kierownik archiwum Naczelnikowi Wydziału Ogólnego, drugi - zwierzchnikowi jednostki administracyjnej, które akta wypożyczyła, trzeci składa do akt składnicy. Dalszy tok załatwienia zależny jest od Prezydenta Miasta, któremu Naczelnik Wydziału Ogólnego składa odpowiedni wniosek.

$\S 50$.

Jeżeli wypożyczająca jednostka administracyjna nie zwróci akt w oznaczonym terminie, urzędnik składnicy przypomni naczelnikowi wydziału o konieczności 
zwrotu wypożyczonych akt. Jeżeli jednostka administracyjna nie zwróci akt w ciągu trzech dni od przypomnienia, Kierownik Archiwum zawiadamia o tym Naczelnika Wydziału Ogólnego, który wyda w tej sprawie ostateczną decyzję po porozumieniu się z zainteresowaną jednostką administracyjną.

$\S 51$.

Karty wypożyczenia otrzymują numer kolejny w obrębie roku kalendarzowego. Numer wpisuje składnica w odpowiednim miejscu pierwszej i drugiej części karty.

Karty układa się w osobnej skrzynce, w kolejności ich numerów. Karty wypożyczenia przechowuje się przez 2 lata.

\section{$\S 52$.}

Akta kat. a (przechowywane stale) przekazuje składnica do sekcji Akt Dawnych po upływie co najmniej lat 10 od chwili otrzymania tych akt od jednostki administracyjnej.

$\S 53$.

Akta przekazywane do Sekcji Akt Dawnych powinny być uporządkowane zgodnie z przepisami, według których je tworzono.

\section{$\S 54$.}

Składnica sporządza w dwóch egzemplarzach spis akt przekazywanych do Sekcji Akt Dawnych.

Do spisu wciąga się akta według wydziałów, a wewnątrz wydziałów w porządku chronologicznym.

Spisy otrzymują nieprzerwaną kolejną numerację.

Spisy podpisują: urzędnik składnicy i kierownik Archiwum.

Pierwszy egzemplarz spisu otrzymuje Sekcja Akt Dawnych, drugi pozostaje w składnicy.

Składnica i Sekcja Akt Dawnych przechowują spisy w specjalnych teczkach, ułożone w kolejności numerów.

\section{$\S 55$.}

Centralna Składnica Akt pozostaje pod stałym nadzorem kierownika Archiwum.

Ponadto Naczelnik Wydziału Ogólnego dokonuje inspekcji Centralnej Składnicy Akt, oraz Sekcji Akt Dawnych przynajmniej dwa razy do roku w celu sprawdzenia, czy prace Archiwum odbywają się zgodnie z regulaminem niniejszym.

$\S 56$.

Organa państwowej służby archiwalnej (delegaci Wydziału Archiwum Państwowych Min. W. R. i O. P.) mają prawo do dokonywania wizytacji Archiwum 
Miejskiego na podstawie pisma Dyrektora Archiwów Państwowych upoważniającego do dokonania inspekcji.

\section{Rozdział VII.}

Przepisy przejściowe i końcowe

\section{$\S 57$.}

Akta znajdujące się w Archiwum Miejskim w chwili wejścia w życie niniejszego regulaminu należy uporządkować zgodnie z niniejszymi przepisami.

Uporządkowania akt dokona Archiwum przy ewentualnej pomocy odpowiednich jednostek administracyjnych Zarządu Miejskiego w Lublinie.

\section{$\S 58$.}

Regulamin niniejszy wchodzi w życie z dniem ogłoszenia w Dzienniku Zarządu Miejskiego w Lublinie.

(一) B. Liszkowski

Prezydent Miasta

Lublin, dnia 8 lipca 1939 r.

Nr Og. 56/17/39 
Str 64

Dziennik Zarzadu m. Lublina

Nr 2.

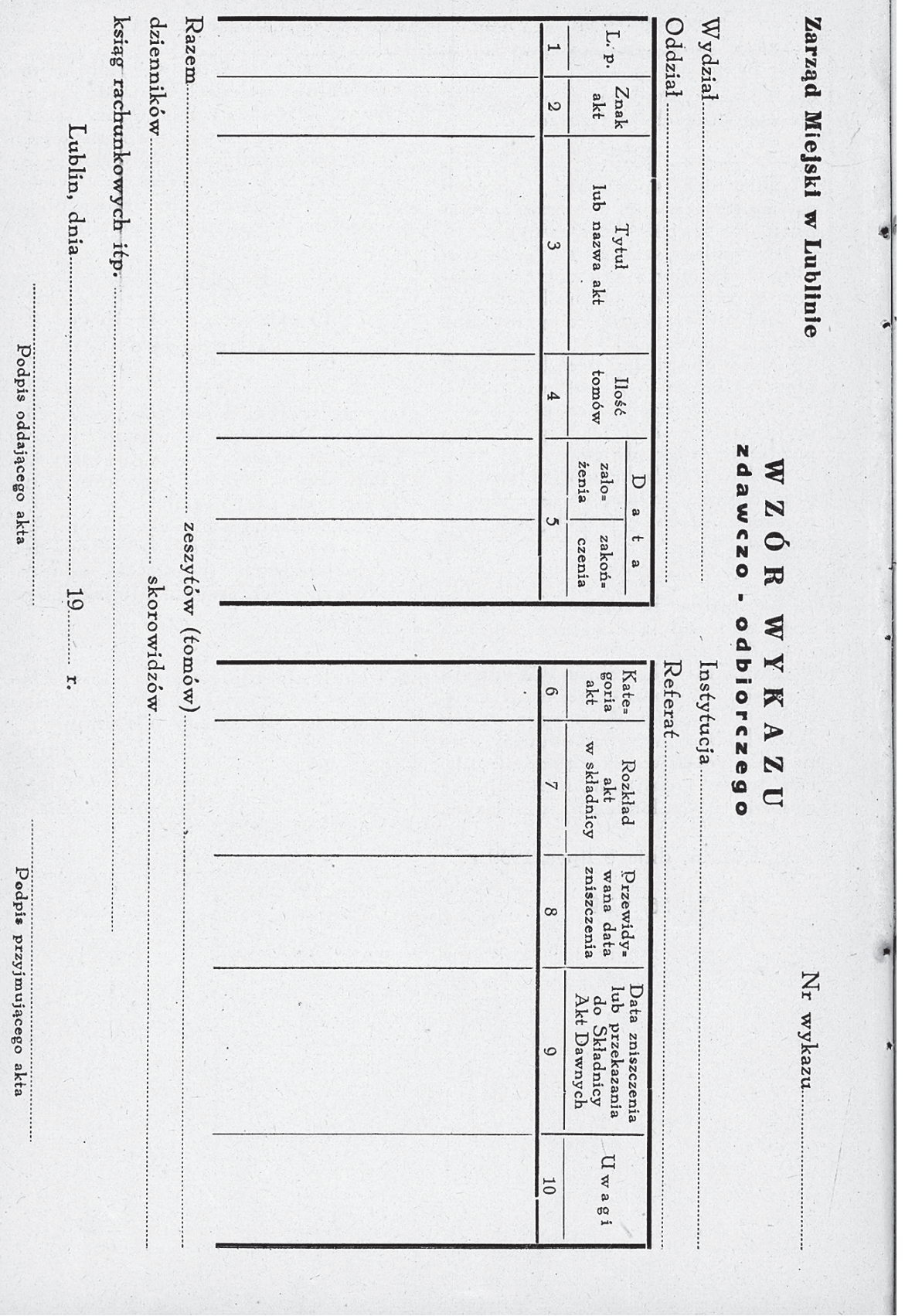

Wzór wykazu zdawczo-odbiorczego, „Dziennik Zarządu m. Lublina” nr 2, 1939. s. 64 
Wzór spisu wykazów zdawczo-odbiorczych

\begin{tabular}{|c|c|c|c|c|c|c|}
\hline $\begin{array}{l}\mathrm{Nr} \\
\text { kat. }\end{array}$ & $\begin{array}{c}\text { Nx wy } \\
\text { kazu } \\
\text { zdawczo- } \\
\text { odbiorcz }\end{array}$ & $\begin{array}{c}\text { Data } \\
\text { przeka- } \\
\text { zania }\end{array}$ & $\begin{array}{l}\text { Nazwa jednostki administrac. } \\
\text { przekazującej akta }\end{array}$ & $\begin{array}{c}\text { Ilosć } \\
\text { pozycji }\end{array}$ & $\begin{array}{l}\text { Ilość } \\
\text { tomów }\end{array}$ & $U_{w a g i}$ \\
\hline 1 & 2 & 3 & 4 & 5 & 6 & 7 \\
\hline & & & & & & \\
\hline & & & & & & \\
\hline & & & & & & \\
\hline & & & & & & \\
\hline & & & & & & \\
\hline & & & & & & \\
\hline & & & & & & \\
\hline & & & & & & \\
\hline & & & & & & \\
\hline
\end{tabular}

Wzór pieczęci Centralnej Składnicy Akt

Zarzad Miejski w Lublinie Centralna Składnica Akt

Sýgnatura

aktu

Szafa

Półka

Wzór spisu wykazów zdawczo-odbiorczych, „Dziennik Zarządu m. Lublina” nr 2, 1939. s. 65 


\section{Wzór karty wypożyczenia}

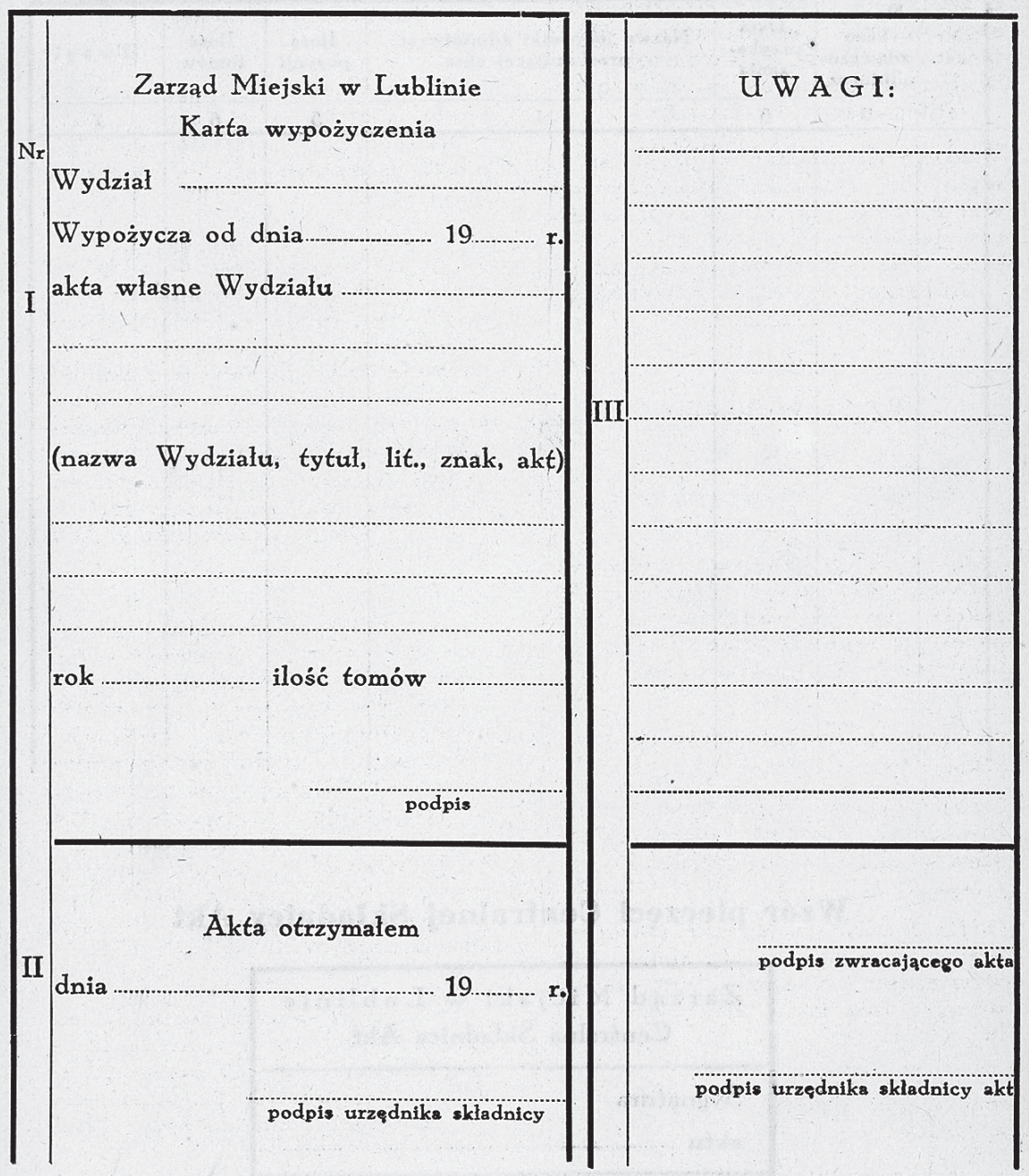

Wzór karty wypożyczenia, „Dziennik Zarządu m. Lublina” nr 2, 1939. s. 66 


\section{Nr 2}

1939 [b.m. i d.]

\section{druk: Dziennik Zarządu m. Lublina z dnia 7 września 1939 r., nr 3, s. 56-61}

Przepisy o przechowaniu i brakowaniu akt w kancelariach wydziałów, przedsiębiorstw i zakładów Zarządu Miejskiego w Lublinie

wydany ${ }^{\mathrm{c}}$ przez Prezydenta Miasta na podstawie art. 46 ustawy z dnia 23 marca 1933 r. o częściowej zmianie ustroju samorządowego i terytorialnego (Dz. U. R. P. nr 15, poz. 294).

\section{Rozdział I \\ Przepisy Ogólne}

\section{$\S 1$.}

Kancelaria przechowuje wszystkie akta zakończone przez lat dwa do pięciu. Następnie akta już niepotrzebne do pracy bieżącej, kancelaria przekazuje do centralnej składnicy akt Zarządu Miejskiego w Lublinie, nazywanej dalej „składnicą”.

\section{$\S 2$.}

Przy obliczeniu czasu przechowywania akt nie bierze się w rachubę roku, w którym zakończono je, jak również roku ich przekazania do składnicy.

\section{Rozdział II \\ Przechowywanie akt}

\section{$\S 3$.}

Wszelkie akta winny być przechowywane w składnicach w sposób i w warunkach określonych Regulaminem Organizacyjnym Archiwum Miejskiego w Lublinie, nazywanego dalej „regulaminem”.

\section{Rozdział III}

Porządkowanie akt

\section{$\S 4$.}

Akta przekazywane do składnicy powinny być uporządkowane według zasad tego systemu, który stosowano przy ich tworzeniu.

\section{$\S 5$.}

Przed uporządkowaniem należy zbadać według jakiego systemu akta były tworzone.

\footnotetext{
c Winno być „wydane”.
} 


\section{$\S 6$.}

Akta tworzone według systemu nowego powinny być uporządkowane w sposób niżej opisany. Ponadto akta szyte kat. A i kat. B gr. I i II i (§ 28 regulaminu) należy zszywać na dwa lub trzy ściegi w sposób powszechnie stosowany.

\section{$\S 7$.}

Przed zszyciem akta układa się w teczkach (obwolutach) według spraw, w porządku w chronologicznym. Akta w obrębie danej sprawy układa się według kolejności numerów spisu spraw lub w porządku chronologicznym.

\section{$\S 8$.}

Po ułożeniu akta numeruje się, stawiając numer kolejny ołówkiem zwykłym lub kolorowym, w prawym górnym rogu każdej karty. Broszury, ulotki, odezwy itp., numeruje się podobnie jak zwykłą korespondencję, tzn. każdą kartę z osobna. Kartą nazywa się każda kartka papieru, nie zależnie od wielkości. Każda teczka (tom, akt) ma osobną numerację wewnętrzną.

\section{$\S 9$.}

Papiery już ułożone i ponumerowane wszywa się legami po 5-10 kart. Niezapisanych kart wszywać nie należy.

$\S 10$.

Planów, dokumentów osobistych świadectw, fotografii itp., które mogą być wydawane $\mathrm{z}$ akt, lub mogłyby ulec uszkodzeniu przy wszywaniu, nie wszywa się, lecz wkłada do specjalnych kopert podklejonych płótnem, a następnie wszywa się do wkładki przez załam koperty. Na kopercie wypisuje się ich zawartość. W razie zwrotu dokumentu, odbiorca stwierdza na kopercie jego otrzymanie lub registrator notuje, gdzie się znajduje pokwitowanie.

\section{$\S 11$.}

Książki mające ponad 48 stron, plany, mapy, rysunki większych rozmiarów itp. traktować należy jako załącznik i przechowywać oddzielnie, robiąc odpowiednie omówienie na okładce akt. Taką samą notatkę czyni się na książce, mapie lub rysunku oraz na akcie, do którego były dołączone.

$\S 12$.

Teczka (tom - akt) nie powinna zawierać więcej niż 300 do 400 kart. Grubość teczki w grzbiecie nie powinna przekraczać $5 \mathrm{~cm}$.

$\S 13$.

Do teczki (tomu) akt dołącza się spis treści (spis spraw). 
$\S 14$.

Jeżeli akta sprawy składają się z kilku tomów, to wszystkie tomy noszą ten sam tytuł. Każdy tom stanowi odrębną całość i powinien mieć osobną numerację wewnętrzną. Tomy akt noszą kolejne numery rzymskie. Na każdym zakończonym tomie, za jego numerem kolejnym, robi się dopisek: „następuje tom” lub „tom końcowy”.

$\S 15$.

Przy aktach przechowywanych stale, okładka (obwoluta) teczki składa się: a) obwoluty i b) wkładki do wszywania akt.

$\S 16$.

Obwoluty mają być z papieru okładkowego w dobrym gatunku. Wielkość obwoluty należy dostosować do formatu papieru. Brzegi obwolut powinny wystawać o $1 \mathrm{~cm}$ ze wszystkich trzech stron poza papiery, znajdujące się wewnątrz obwoluty. Obwoluty akt poszczególnych wydziałów i przedsiębiorstw mają odmienną barwę rozpoznawczą. Barwę obwolut dla każdego wydziału i przedsiębiorstwa ustala Naczelnik Wydziału Ogólnego, w porozumieniu za zwierzchnikiem jednostki administracyjnej.

$\S 17$.

Wkładka do wszywania akt powinna być z miękkiego papieru aktowego, podklejonego płótnem krawieckim. Wkładka ma długość obwoluty, a szerokość od 12 do $15 \mathrm{~cm}$. Wkładkę wraz z aktami wszywa się przez jej środek w grzbiet obwoluty.

$\S 18$.

Pierwsza strona obwoluty powinna mieć tytuł akt w/g ustalonego wzoru.

$\S 19$.

Do pierwszej strony obwoluty od spodu przyszywa się tzw. ,język" i impregnowanego płótna lub z tego samego co obwoluta papieru, złożonego we dwoje. Długość języka wynosi $20 \mathrm{~cm}$ szerokość zaś od 8 do $10 \mathrm{~cm}$. Na zewnątrz teczki powinno wystawać $10 \mathrm{~cm}$ języka. Na języku wpisuje się w skrócie: 1) nazwę wydziału lub przedsiębiorstwa, b) znak akt, c) numer kolejny tomu.

$\S 20$.

Gdy akta przenoszone są z jednej jednostki administracyjnej do drugiej, należy wszyć je do nowej okładki nie odejmując starej. Nowa okładka otrzymuje odpowiedni tytuł.

$\S 21$.

Papiery przechowywane $\mathrm{w}$ se- ${ }^{\mathrm{d}}$ gregatorów i stworzyć z nich akta.

${ }^{\mathrm{d}}$ Brak co najmniej jednego wiersza tekstu. 


\section{$\S 22$.}

Na księgach, mających grzbiety Z szarego płótna robi się napisy czarnym tuszem przy pomocy liter i cyfr, lub pędzelkiem przy pomocy szablonu. Napis na grzbiecie powinien być następujący poczynając od góry: a) pierwsza litera (lub litery) nazwy jednostki administracyjnej (tzw. cecha), b) numer kolejny tomu, c) tytuł (nazwa) księgi, d) rok, a w razie potrzeby także dzień i miesiąc, oraz numery graniczne kart.

\section{$\S 23$.}

Wypożyczanie akt w obrębie własnej jednostki administracyjnej odbywa się na zasadach określonych instrukcją kancelaryjną.

\section{Rozdział IV.}

\section{$\S 24$}

Akta kategorii B grupy IV (przechowywane 2 do 5 lat) ulegają brakowaniu w kancelarii danej jednostki administracyjnej.

\section{$\S 25$.}

Corocznie po 2-5-letnim przechowywaniu akt kat. B grupy IV wpisuje się do wykazu zdawczo-odbiorczego akt przekazywanych do składnicy. W rubryce 9-ej wykazu umieszcza się datę faktycznego ich zniszczenia, tzn. datę podpisania protokółu zniszczenia.

\section{$\S 26$.}

Wydzielenia akt dokona według przepisów niniejszych urzędnik przechowujący akta $\mathrm{w}$ danej jednostce administracyjnej na podstawie szczegółowego wykazu akt, z podziałem na kategorie i grupy. Prawidłowość wydzielenia sprawdza zwierzchnik danej jednostki administracyjnej lub delegowany przez niego urzędnik. $Z$ dokonanego wydzielenia spisuje się protokół w dwóch egzemplarzach, zawierający tytuły akt wydzielonych. Protokół podpisują:

1) urzędnik przechowujący akta w danej jednostce administracyjnej i 2) zwierzchnik tej jednostki administracyjnej. Jeden egzemplarz protokółu zostaje przesiany kierownikowi składnicy akt, drugi pozostaje $\mathrm{w}$ aktach danej jednostki administracyjnej.

\section{$\S 27$.}

Akta wybrakowane przesyła się do miejskiego składu makulatury.

\section{Rozdział V.}

Przekazywanie akt do składnicy 


\section{$\S 28$.}

Przy przekazywaniu akt do składnicy należy stosować się do przepisów regulaminu organizacyjnego Archiwum Miejskiego w Lublinie.

\section{Rozdział VI.}

Brakowanie akt

\section{$\S 29$.}

Brakowanie akt składa się z dwóch czynności:

a) oceny akt,

b) wydzielenie akt przechowywanych czasowo (kat. B).

\section{Ocena akt}

\section{$\S 30$.}

Ocena akt polega na ich zaliczeniu do kat. A lub B, z oznaczeniem grupy.

Podstawą oceny są szczegółowe wykazy akt z podziałem na kategorie i grupy. Wykazy te sporządzają jednostki administracyjne w porozumieniu z Wydziałem Ogólnym, a zatwierdza je Prezydent Miasta.

\section{$\S 31$.}

Stemple oceny akt (wzór Nr 1) stawia urzędnik przechowujący akta w odnośnej jednostce administracyjnej przy rozpoczęciu księgi lub teczki akt:

a) w aktach na okładce każdego zeszytu,

b) w księgach buchalteryjnych na pierwszej czystej karcie.

\section{$\S 32$}

Oceny akt dokonuje kierownik kancelarii lub rachuby po zakończeniu tomu czy księgi, przekreślając na stemplu oceny odpowiednie wyrazy, albo wstawiając liczby w odpowiednie okienka.

\section{$\S 33$.}

Na podstawie podanej oceny urzędnik przechowujący akta ustala przed przekazaniem do składnicy rok zniszczenia akt i wpisuje do 8-ej rubryki wykazu zdawczo-odbiorczego.

\section{Wydzielanie akt}

\section{$\S 34$.}

Kierownik składnicy wydziela corocznie te akta kat. B, które mogą być w bieżącym roku zniszczone, kierując się datami podanymi w 8 rubryce wykazów zdawczo-odbiorczych. 
Przy wydzielaniu akt nie wolno powodować się tylko ich tytułem lecz należy przejrzeć dokładnie same akta, każdy zeszyć, karta po karcie.

Po wydzieleniu kierownik składnicy:

a) przekreśla (zwykłym ołówkiem) w wykazach zdawczo-odbiorowych numery kolejne akt wydzielonych,

b) układa akta wydzielone w takim porządku, w jakim figurują one w wykazach zdawczo-odbiorczych i wiąże w paczki. Grubość paczki nie powinna przekraczać $30 \mathrm{~cm}$.

Na wierzchu każdej paczki umieszcza się kartę z napisem: „Wydział akta wydzielone. Wykaz zdawczo-odbiorczy $\mathrm{Nr}$...”

W jednej paczce nie należy mieszać ze sobą akt różnych wydziałów.

$\S 35$.

Kierownik składnicy ma prawo stawiania uzasadnionych wniosków na przesunięcie akt kat. B z grupy niższej do wyższej oraz akt kat. B do kat. A.

Decyzje w tej sprawie wydaje Naczelnik Wydziału Ogólnego po porozumieniu się ze zwierzchnikiem jednostki administracyjnej, która odnośne akta przekazała do składnicy.

\section{$\S 36$.}

Akta przesunięte do innej kategorii (grupy) kładzie kierownik składnicy na dawne miejsce, poczym zamienia atramentem czerwonym przewidywany rok zniszczenia w 8 rubryce wykazu zdawczo-odbiorczego.

\section{$\S 37$.}

Celem sprawdzenia czynności kierownika składnicy, Naczelnik Wydziału Ogólnego zwołuje raz na rok komisję sprawdzającą w składzie:

a) zwierzchnik lub delegowany przez niego referent jednostki administracyjnej, której akta zostały wydzielone,

b) Naczelnik lub delegowany przez niego referent Wydziału Ogólnego,

c) kierownik składnicy.

Komisja sprawdzająca bada prawidłowość wydzielenia akt i spisuje protokół z dokonanych czynności (wzór nr 2).

W protokóle wymienia się numery wykazów zdawczo-odbiorczych oraz numery poszczególnych pozycji akt przeznaczonych do zniszczenia.

Pierwszy egzemplarz protokółu kierownik składnicy składa do akt, drugi przesyła odpowiedniej jednostce administracyjnej.

\section{$\S 38$.}

Numery kolejne protokółu zdawczo-odbiorczego, przekreślone poprzednio ołówkiem, kierownik składnicy po zakwalifikowaniu akt przez komisję sprawdzającą do zniszczenia, przekreśla atramentem czerwonym i stawia w rubryce 9-ej tegoż protokółu datę zniszczenia oraz swój znak. 
Za datę zniszczenia uważa się datę podpisania protokółu przez komisję sprawdzającą.

Protokóły z czynności komisji sprawdzających przechowuje składnica według Wydziałów (przedsiębiorstw) w porządku chronologicznym (każdy wydział w osobnej teczce).

\section{$\S 39$.}

Akta wybrakowane składa się w magazynie makulatury. Gdy zebrała się ich większa ilość, sprzedaje się je na przeróbkę w fabryce papieru z wyjątkiem akt, wymienionych $\mathrm{w} \S 40$.

Przed tym należy:

a) odjąć te części składowe akt, które nadają się do użytkowania jak: oprawa (karton, płótno), niezniszczone obwoluty, teki kartonowe, czysty papier,

b) doprowadzić akta do stanu nieużywalności (pruje się księgi buchalteryjne i zeszyty akt, rozrzuca się karty i miesza je ze sobą).

Nabywca winien poświadczyć na piśmie jaką ilość (w kilogramach) nabył i zobowiązać się do przerobienia nabytej makulatury na masę papierową oraz do tego, że makulatura nie będzie przed przeróbką przez nikogo przeglądana.

$\S 40$.

Przez spalenie niszczy się wybrakowane:

a) akta tajne,

b) dowody kasowe,

c) akta, które zakwalifikuje do spalenia komisja sprawdzająca.

Spalenie odbywa się w obecności Naczelnika Wydziału Ogólnego lub delegowanego przezeń urzędnika, kierownika składnicy i przedstawiciela samodzielnego Oddziału Kontroli.

$\S 41$.

Przepisy niniejsze wchodzą w życie z dniem ogłoszenia ich w Dzienniku Zarządu m. Lublina.

(一) B. Liszkowski

Prezydent Miasta 


\section{W 26 r Nr 1}

Do $\S 31$ przepisów o przechowaniu akt w kancelariach wydziałów

Kat. A. (zachować zawsze)

Kat. B. grupa

Przechowywać lat

Lublin, dn. $19 \ldots . . . . x$

Kierownik biura

\section{W z ó r Nr 2}

Protokól czynności komisji sprawdzajacej z dnia $19 \ldots . .$. r.

Komisja sprawdzajaca w składzie:

1) Naczelnik (referent) Wydzialu Ogólnego

2) Naczelnik (Dyrektor)

3) Kierownik skladnicy akt

Po obejrzeniu akt wydziału (przedsiębiorstwa)

wydzielonych przez kierownika składnicy akt, komisja zakwalifikowala do zniszczenia akt następujące:

1) Wykaz zdawczo odbiorezy $\mathrm{Nr}$

Numery pozycji

2) Wykaz zdawczo=odbiorczy $\mathrm{Nr}$

Numery pozycji:

Przez spalenie zniszczyć należy akta-numery pozycji:

Protokól niniejszy sporządzono w 2=ch egzemplarzach.

Lublin, dnia 19 r.

Podpisy:

Wzory stempla oceny akt i protokołu czynności komisji sprawdzającej, „Dziennik Zarządu m. Lublina" nr 3, 1939. s. 61 